Roman Kroufek, Vlastimil Chytrý

Czech Republic

Miriam Uhrinová

Slovakia

\title{
The Effect of the Type of the Finished High School on the Nature Relatedness of Pre-service Primary Teachers
}

DOI: 10.15804/tner.2018.54.4.19

\begin{abstract}
The paper deals with an individual's nature relatedness and a selected significant variable which may have an effect on it; especially it researches the studied high school relation to nature relatedness in primary school teacher trainees. It is research in quantitative design, using a questionnaire to collect data. The questionnaire was based on the Nature Relatedness Scale. Results show a significant effect of the type of high school finished on students' nature relatedness. The highest scores in the construct analysed were obtained in nature and science-oriented branches, the lowest by graduates of social sciences and general grammar schools. Such results confirm the significance of education in natural science in forming a positive attitude to nature and disprove the cliché ideas of polytechnics producing environmentally insensitive graduates.
\end{abstract}

Keywords: nature relatedness, primary school, environmental literacy

\section{Introduction}

Traditionally, the aims of environmental education are defined by a number or variables (UNESCO, 1977), lately often described as a complex construct called environmental literacy (Roth, 1992; Hungerford et al., 1994). If we accept the multidimensional approach to environmental literacy according to the North American Association for Environmental Education (Hollweg et al., 2011), the 
most frequent aim of researchers would probably be its affective dimension, called disposition; within its frame the research is mostly aimed at environmental attitude (Dunlap \& Van Liere, 1978; Dunlap, 2008), the focus of control, self-assurance of one's own influence (Peyton \& Miller, 1980; Hines et al., 1987) together with environmental sensitivity (Chawla, 1998).

Environmental sensitivity may, in its broader sense, be identified with an individual's attitude to nature. It represents a topic of significance and is in the center of growing professional interest (Restall \& Condrad, 2015). Knowing the relation of a child, student or adult course attendee to nature along with the ability to measure it may serve as an interesting source of environmental education evaluation (Liefländer et al., 2013). The ways to measure one's nature relatedness through quantitative approaches are based on using original research tools consisting mostly of scales focused on particular constructs of an individual's nature and nature environment relatedness.

One of the early tools aimed at an individual's nature relatedness is the unidimensional Inclusion of Nature in Self Scale (Schultz, 2002). Another one is a 14-item tool called Connectedness to Nature Scale (Mayer \& Frantz, 2004), measuring the respondent's affiliation to the natural world and their emotional link to it.

The Nature Relatedness Scale - NRS (Nisbet et al., 2009; Nisbet, 2011) has been its author's cherished tool, being a 21-item scale based on the biophilia hypothesis (Wilson, 1984; Kellert \& Wilson, 1993). The respondent expresses their level of consent with every item on a standard five-point Likert scale. NRS is aimed at a construct called nature relatedness by its author: "The concept of nature relatedness encompasses one's appreciation for and understanding of our interconnectedness with all other living things on the Earth... It is not simply a love of nature or enjoyment of only the superficially pleasing facets of nature, such as sunsets and snowflakes. It is also an understanding of the importance of all aspects of nature, even those that are not aesthetically appealing to humans" (Nisbet et al., 2009, p. 718 ). This concept covers the affective, cognitive as well as physical dimension of an individual's relation to nature. The metacognitive dimension (Říčan, 2016) is not covered. The authors differentiated three factors (Nisbet et al., 2009).

In their further studies, the same authors proved that the nature relatedness construct is a predictor of a person's ease and sanity (Nisbet et al., 2011). Similar results were found in experiments analysing the influence of nature sojourn or watching nature documentaries on a person's sense of happiness and environmentally responsible behavior (Nisbet \& Zelenski, 2011; Zelenski et al., 2015). Also, 
a meta-analysis involving NRS together with CNS and INS (Capaldi et al., 2014) proved a certain bondage of one's attitude to nature within a wider frame.

In 2013, Nisbet \& Zelenski (2013) offered an abridged and modified version of a tool called NR-6. As seen in the name, it only consists of six items selected from NR sub-scores self and NR experience. NR-6 strongly positively correlates with the original tool $(\mathrm{r}=0.91)$ and the authors recommend it as an optional alternative (Nisbet \& Zelenski, 2013).

\section{Research Problem}

The primary school teacher can have a significant effect on forming environmental attitudes in a student or their base in terms of the student's attitude to nature, where such attitudes are formed. That is also why we need to investigate important milestones influencing the teacher's characteristics, where without any doubt the high school education belong.

\section{Research Focus}

The aim of the research was to find the answers to the following questions, with the use of the NRS scale and its abridged version:

1. Where is the potential of using the NRS scale and its abridged version NR-6 with primary school teacher trainees?

2. In what way is primary school teacher trainees' nature relatedness influenced by their previously attended high school?

\section{$\underline{\text { Research Methodology }}$}

\section{Research General Background}

The research design is quantitative, with the use of collecting data through a questionnaire. The data was obtained from students at Czech universities. The students' participation was voluntary. The data collected was anonymous and was only used for the purposes of the research and is in no relation to the results of the students' studies. For the above-mentioned reasons, we do not disclose the names of the institutions involved in data collection.

\section{Research Sample}

The sample of respondents consisted of 917 primary school teacher trainees from selected universities in the Czech Republic. With regard to the characteristics of the research, a balanced sample is not offered in terms of gender (52 male and 
865 female respondents). The selection of the students covered all forms of their five-year study. The sample size is adequate for the research (Bartlett et al., 2001).

\section{Instrument and Procedures}

The research tool chosen was a questionnaire consisting of items focusing on the respondents' demographic background (their age, gender), high school attended prior to university studies and also items from the Nature Relatedness Scale (Nisbet et al., 2009), in its translation into Czech by Franěk (2012). The scale covers 21 items, answers to each item are noted on a Likert-type scale in the following terms: strongly disagree - partly disagree - neither agree nor disagree - partly agree - strongly agree. Within the frame of the above-mentioned scale, they separately followed the items of an abridged version NR-6 (Nisbet \& Zelenski, 2013). The sum of individual items was used to evaluate individual scales. The questionnaire was in its material form distributed to the respondents during 2015; the respondents took about 20 minutes to fill their forms in.

\section{Data Analysis}

The data were analysed using Statistica 12 software (Statsoft, 2015). To find the reliability of the scales (NRS and NR-6), we used standard methods used in pedagogical research. With tools using a five-point Likert scale for respondents' entries, Cronbach's a coefficient is used to measure internal consistency of the tool.

Normality data testing was realized at a 5\% level of significance with the use of the Shapiro-Wilk normality test, where it was tested against the null hypothesis that the evaluated data has normal distribution. To compare more groups, the non-parametric Kruskal-Wallis ANOVA was used, followed by posthoc analysis (Siegel \& Castellan, 1988). One-percent level of significance was used.

\section{Research Results}

The following values of Cronbach's $\alpha$ coefficient were found in the case of the mentioned scales: NRS $\alpha=0.88$, NR- $6 \alpha=0.85$. The reliability may be considered excellent in both cases. The content validity was guaranteed through generally accepted scales repeatedly used with success in influential research (Nisbet et al., 2009; Nisbet et al., 2011; Craig et al., 2016). Predictive validity was illustrated by our research results. According to the Shapiro-Wilk normality test results, the null hypothesis with the normal distribution of data is to be rejected within NRS $(\mathrm{W}=0.97 ; \mathrm{p}<0.001)$ as well as within NR-6 (W = 0.97; $\mathrm{p}<0.000)$ and only 
nonparametric methods of statistical analysis are to be counted on in further research. The whole calculation will be performed by the Robinson and Levin (1997) two-step model. As a guideline for assessing the significance of the results, statistically unimagined by the range of the analyzed set, the effect size coefficients will be used (Cohen, 1988; Morse 1999; Sheskin, 2007; Thomas \& Nelson, 2001). These coefficients eliminate the influence of positive dependence on statistical significance on the set size (Rosenthal, Rosnow, \& Rubin, 2000).

\section{Kruskal-Wallis ANOVA analysis and $\operatorname{eta}^{2}\left(\eta^{2}\right)$}

As seen in the NRS $(H=128.95 ; p<0.001)$ and NR-6 $(H=142.32 ; p<0.001)$, statistical significance of the variable "high school" is to be found and the null hypothesis at the one-percent level of significance is to be rejected. Substantive significance is calculated in this case, using the $\eta^{2}$ coefficient, which is an example of the effect size coefficient associated with Kruskal-Wallis ANOVA. The observed values $\eta^{2}=0.136$ for NRS and $\eta^{2}=0.151$ for NR- 6 indicate a mean effect in the NRS scale $\left(\eta^{2} \epsilon<0,06-0,14>\right)$ and a large effect for NR6 $\left(\eta^{2}>0,14\right)$. It is, therefore, necessary to gain a closer insight into the issue. The results of posthoc analysis shown in Table 1.

Table 1. Posthoc analysis for the NRS scale

\begin{tabular}{lcccccc}
\hline & $\begin{array}{c}\text { Educa- } \\
\text { tional }\end{array}$ & Economic & $\begin{array}{c}\text { Grammar } \\
\text { School }\end{array}$ & $\begin{array}{c}\text { Social } \\
\text { Services }\end{array}$ & $\begin{array}{c}\text { Polytech- } \\
\text { nics }\end{array}$ & $\begin{array}{c}\text { Natural } \\
\text { Science }\end{array}$ \\
\hline Educational & & $p=0.523$ & $p=0.017^{\star}$ & $p<0.001^{\star *}$ & $p=0.037^{\star}$ & $p<0.001^{\star}$ \\
\hline Economic & $p=0.523$ & & $p<0.001^{\star *}$ & $p<0.001^{\star *}$ & $p=0.435$ & $p=0.085$ \\
\hline Grammar School & $p=0.017^{\star}$ & $p<0.001^{\star *}$ & & $p<0.001^{\star *}$ & $p<0.001^{\star *}$ & $p<0.001^{\star *}$ \\
\hline Social Services & $p<0.001^{\star *}$ & $p<0.001^{\star *}$ & $p<0.001^{\star *}$ & & $p<0.001^{\star *}$ & $p<0.001^{\star *}$ \\
\hline Polytechnics & $p=0.037^{*}$ & $p=0.435$ & $p<0.001^{\star *}$ & $p<0.001^{\star *}$ & & $p=0.673$ \\
\hline Natural Science & $p<0.001^{* *}$ & $p=0.085$ & $p<0.001^{\star *}$ & $p<0.001^{\star *}$ & $p=0.673$ & \\
\hline
\end{tabular}

Note: Values in bold are statistically significant: ${ }^{*}$ the level of significance $p=0.05,{ }^{*}$ the level of significance $p=0.01$

The table shows that the greatest differences occur between social and other types of high schools, where there were statistically significant differences in all the cases. It is of interest to notice grammar school, where there was a difference found with other types of schools, excluding educational schools.

Individual differences are presented in Table 2, compiled on the basis of descriptive analysis and also Graph 1 . With regard to the nonparametric character of the data, the median values are determinants for the detection of the difference. 
Table 2. Descriptive analysis results with NRS

\begin{tabular}{lcccccc}
\hline Educational & Economic & $\begin{array}{c}\text { Grammar } \\
\text { School }\end{array}$ & $\begin{array}{c}\text { Social Ser- } \\
\text { vices }\end{array}$ & $\begin{array}{c}\text { Polytech- } \\
\text { nics }\end{array}$ & $\begin{array}{c}\text { Natural } \\
\text { Science }\end{array}$ \\
\hline$\varnothing$ & 75.03 & 77.43 & 71.24 & 53.86 & 80.25 & 83.41 \\
\hline $\mathrm{Me}$ & 79.00 & 81.00 & 73.00 & 54.00 & 85.00 & 84.00 \\
\hline $\mathrm{Mod}$ & 83.00 & 83.00 & 81.00 & 55.00 & 86.00 & 79.00 \\
\hline SD & 13.88 & 14.30 & 14.60 & 7.31 & 13.15 & 8.83 \\
\hline
\end{tabular}

Table 2 shows that social service schools are significantly different from other types of schools. The students of such schools belong to the group with the lowest median, meaning their nature relatedness is remarkably lower than that of the students of other types of schools.

Grammar schools in their median are also differentiated from other school types, only not as much as in the case of social service schools. It is rather surprising that at the one-percent level of significance no differences between educational schools and polytechnics (Me 85) were found, unlike the difference between educational and natural science schools (Me 84), it was statistically significant.

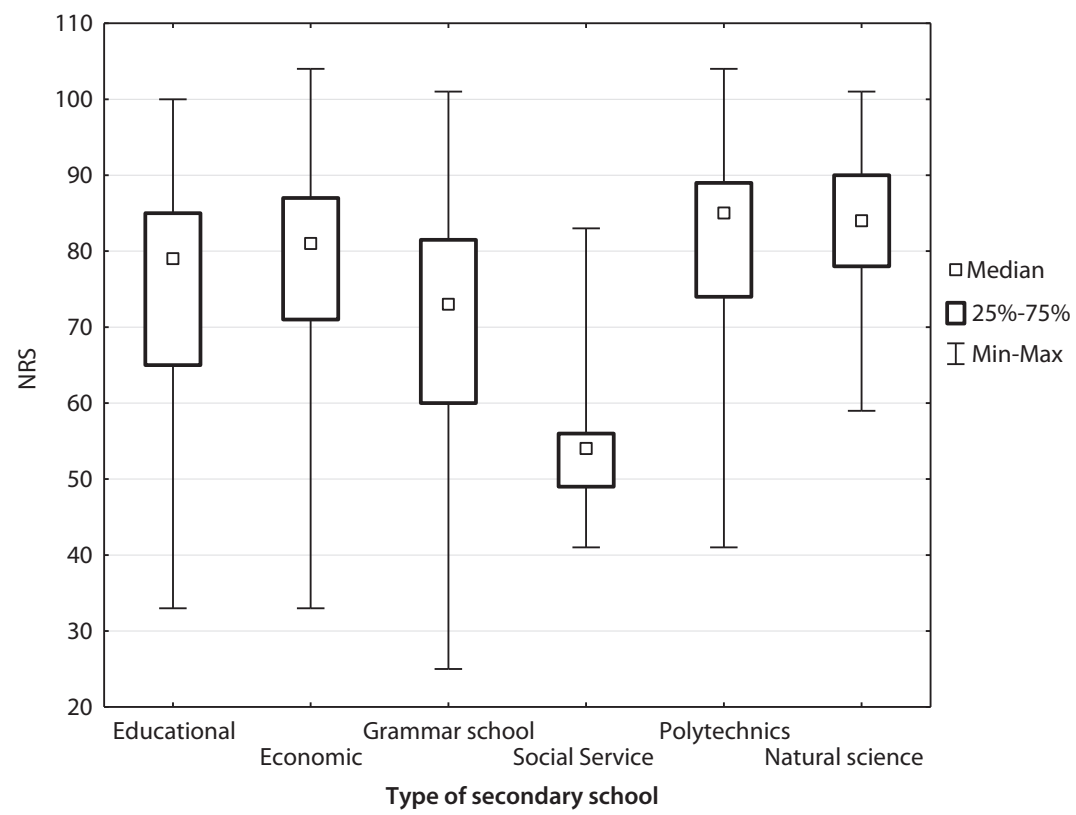

Figure 1. Boxplot NRS 
The above-mentioned subtleties in results are best explained through a quartile graph showing the difference between educational schools and polytechnics lying in the vertical shift, where the difference in upper and lower quartile is not of much difference as in educational and natural science schools.

As in the case of an entire scale of NRS along with NR-6, the null hypothesis was rejected at the one-percent level of significance. The results of follow-up posthoc analysis are shown in Table 3.

Table 3. Posthoc analysis for the NR-6 scale

\begin{tabular}{lcccccc}
\hline & $\begin{array}{c}\text { Educa- } \\
\text { tional }\end{array}$ & Economic & $\begin{array}{c}\text { Grammar } \\
\text { School }\end{array}$ & $\begin{array}{c}\text { Social } \\
\text { Services }\end{array}$ & $\begin{array}{c}\text { Polytech- } \\
\text { nics }\end{array}$ & $\begin{array}{c}\text { Natural } \\
\text { Science }\end{array}$ \\
\hline Educational & & $p=0.273$ & $p=0.063$ & $p<0.001^{\star *}$ & $p=0.011^{\star}$ & $p<0.001^{\star *}$ \\
\hline Economic & $p=0.273$ & & $p<0.001^{\star *}$ & $p<0.001^{\star *}$ & $p=0.561$ & $p=0.006$ \\
\hline Grammar School & $p=0.063$ & $p<0.001^{\star *}$ & & $p<0.001^{\star *}$ & $p<0.001^{\star *}$ & $p<0.001^{\star *}$ \\
\hline Social Services & $p<0.001^{\star *}$ & $p<0.001^{\star *}$ & $p<0.001^{\star *}$ & & $p<0.001^{\star *}$ & $p<0.001^{\star *}$ \\
\hline Polytechnics & $p=0.011^{\star}$ & $p=0.561$ & $p<0.001^{\star *}$ & $p<0.001^{\star *}$ & & $p=0,588$ \\
\hline Natural science & $p<0.001^{\star *}$ & $p=0.006$ & $p<0.001^{\star *}$ & $p<0.001^{* *}$ & $p=0,588$ & \\
\hline
\end{tabular}

Note: Values in bold are statistically significant: ${ }^{*}$ the level of significance $p=0.05,{ }^{* *}$ the level of significance $p=0.01$

Particular differences are presented in Table 4, set according to descriptive analysis and Figure 2. With the help of the abridged NR-6 scale, it was concluded that the results are almost the same as in the case of the entire NRS scale, which proves, above other things, the possibility to use NR-6 to find results of nature relatedness in the respondents.

Table 4. Descriptive analysis results for NR-6

\begin{tabular}{lcccccc}
\hline Educational & Economic & $\begin{array}{c}\text { Grammar } \\
\text { school }\end{array}$ & $\begin{array}{c}\text { Social Ser- } \\
\text { vice }\end{array}$ & Polytechnics & $\begin{array}{c}\text { Natural } \\
\text { Science }\end{array}$ \\
\hline$\varnothing$ & 19.79 & 21.22 & 18.32 & 11.41 & 22.23 & 23.92 \\
\hline $\mathrm{Me}$ & 21.00 & 21.00 & 19.00 & 12.00 & 23.00 & 24.00 \\
\hline $\mathrm{Mod}$ & 20.00 & 21.00 & 20.00 & 12.00 & 27.00 & 23.00 \\
\hline $\mathrm{SD}$ & 5.41 & 4.62 & 5.93 & 3.72 & 5.14 & 4.04 \\
\hline
\end{tabular}

The concurrence in the results of both scales used is perfectly clear in Figure 2, where a vertical shift occurs more often with NR-6 due to a lower number of items, and the in-between-quartile range is concurrent in more of the groups observed. 


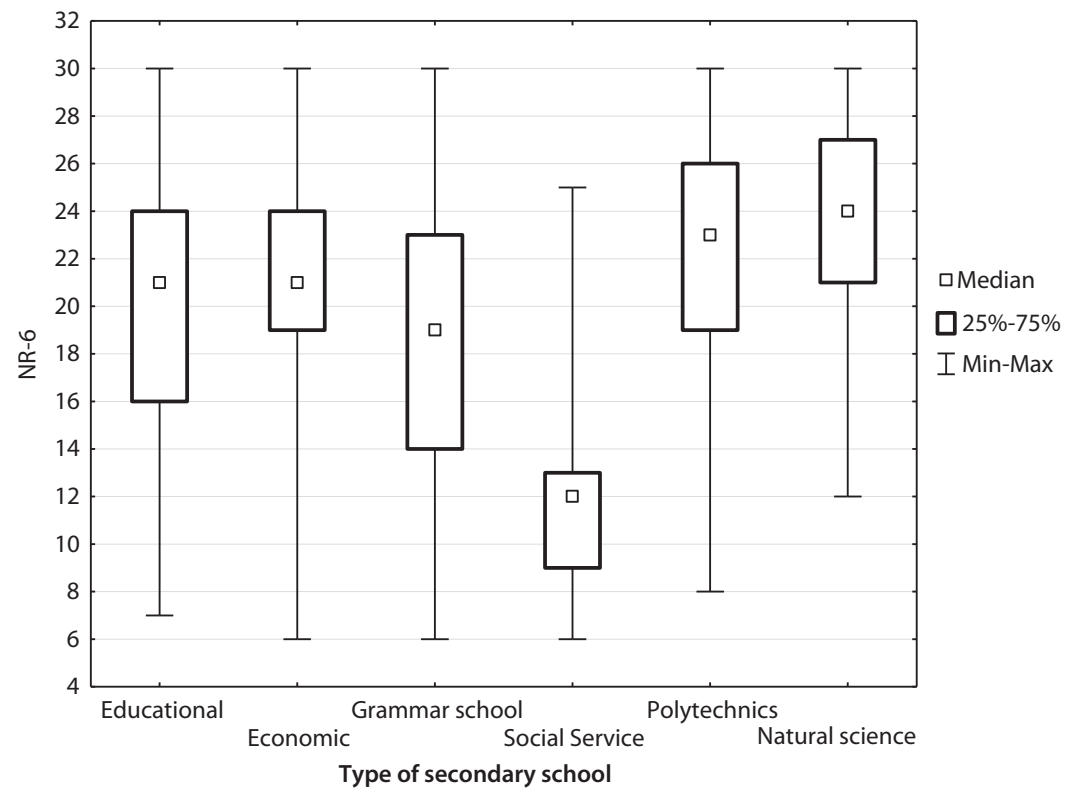

Figure 2. Boxplot NR-6

\section{Discussion}

The first research question was of descriptive nature: "What are the options of NRS and abridged NR-6 version scales in primary school teacher trainees?" The reliability of both scales was verified, and it was found of adequate height in both cases. Similar reliability results with university students were obtained in the studies carried out by Franěk (2012) and Kroufek \& Chytrý (2015). The latter then attracted attention to the low reliability of the abridged NR-6 scale. The results obtained on both scales are practically identical (cf., Tables 1 and 2), which in concordance with Nisbet \& Zelenski (2013) and Craig et al. (2016), who encourage the possible usage of NR-6 instead of its more sophisticated original NRS scale. Options for using the subtle scale in research are opening for cases where there is no need for a large number of items in the research tool (e.g., Bragg et al., 2013; Windhorst \& Williams, 2015). This research complements the idea of the usability of both scales in related cultures and therefore these scales can be used for further research in the Central European context.

The second research question was as follows: In what way is primary school teacher trainees' nature relatedness influenced by their previously attended high school? This was the first time the question about the connection of previously 
attended high school and nature relatedness was investigated. A number of statistical as well as substantive significant differences were observed among the types of high schools through statistical analysis. The highest values, meaning the highest level of nature relatedness, were obtained by the students previously attending natural-science-oriented high schools, which, above other aspects, prove the prognostic validity of both scales used. The higher results obtained by the students previously attending polytechnics are of interest. Such results encourage the idea of polytechnic and environmental thinking, or polytechnic and environmental literacy are in no way contradictory (Janovec et al., 2016), but on the contrary, a large range of "technically oriented" people are very sensitive and their attitude to nature is rather friendly. Similarly, business and educational vocational schools may be considered in the same league. Grammar school graduates receive the most extensive secondary education among the student participants and that is why their results are surprising. On the contrary, the low results obtained by the respondents who had finished social-service-oriented schools were to be expected, in terms of the structure of the nature relatedness construct. The graduates of the above-mentioned vocational schools are probably more affiliated with people and society.

Since nature relatedness is a significant part of the affective dimension of environmental literacy (Hollweg et al., 2011), the findings shown in the paper may help predict suitable educators who could then become in charge of executing environmental education at schools. Adequately environmentally literate and therefore motivated and zealous teachers are the guarantee of successful execution of environmental education (Robottom et al., 2000; Cheng \& So, 2015). It has been repeatedly proven that nature relatedness or some of its aspects positively affect happiness and well-being as well as mental and physical health of people, while helping to overcome anxiety and depression (Nisbet, Zelenski \& Murphy, 2011; Zelenski \& Nisbet, 2014; Dean, Shanahan, Bush, Gaston, Lin, Barber, Franco \& Fuller, 2018). This research draws attention to the fact that while natural, technical and vocational school graduates have a high degree of nature relatedness, higher school graduates, who are more focused on working with society, have statistically lower values. In their future work for society, they are significantly exposed to depression, anxiety and burnout. It is, therefore, appropriate to look for ways to include nature relatedness and, in general, the pleasure of nature, in socially oriented secondary schools.

\section{Limits of the research}

No doubt, there are limits to the research presented; among them there is, especially, the use of an available sample of respondents, which should also be large enough. The results may be slightly adjusted by outlier values. With such a large 
set, the outlier values usually get identified. Since such deviations were not caused by ill measuring or incorrect analysis, they are left within the set we used.

\section{Future research}

The type of high school attended is not the only potential factor influencing nature relatedness in future primary school teachers, even though it has been considered a significant factor. Future research could try and identify other factors supposedly affecting the relatedness. For example, major life experiences, leisure activities, one's parents' education and profession, the length of regular contact with nature, etc.

\section{Conclusions}

The results of the research have proven that the type of high school attended does influence the nature relatedness of primary school teacher trainees. The respondents in natural-science branches reached significantly higher values in measuring the complex construct of nature relatedness than the graduates from educational, social service and grammar schools. Similarly high values were obtained by the polytechnics graduates. The type of high school attended may then not only influence an individual's nature relatedness, but also others who are later in touch with the graduate. In the case of the primary school teachers, the high school they graduated from affects the way environmental education is executed in their future workplace.

Acknowledgements

This article was supported by J.E. Purkyně University in Ústí nad Labem internal grant No.: UJEP-IGS-2018-43-001-1 and UJEP-SGS-2017-43-003.

\section{References}

Bartlett, J.E., Kotrlik, J.W., \& Higgins, C.C. (2001). Organizational Research: determining Appropriate Sample Size in Survey research. Information Technology, Learning, and Performance Journal, 19 (1), 43-50.

Bragg, E., Wood, C., Barton, J., \& Pretty, J. (2013). Measuring connection to nature in children aged 8-12: A robust methodology for the RSPB. University of Essex. 
Capaldi, C.A., Dopko, R.L., \& Zelenski, J.M. (2014). The relationship between nature connectedness and happiness: a meta-analysis. Frontiers in Psychology, 5, 1-15. Retrieved from https://doi.org/10.3389/fpsyg.2014.00976.

Chawla, L. (1998). Significant Life Experiences Revisited: a review of research on sources of environmental sensitivity. Environmental Education Research, 4 (4), 369-382.

Cheng, N.Y.I., \& So, W.M.W. (2015). Teachers' environmental literacy and teaching stories of three Hong Kong primary school teachers. International Research in Geographical and Environmental Education, 24 (1), 58-79.

Cohen, J. (1988). Statistical power analysis for the behavioral science (2 $2^{\text {nd }}$ ed.). Hillsdale, NJ: Erlbaum.

Craig, J.M., Logan, A.C., \& Prescott, S.L. (2016). Natural environments, nature relatedness and the ecological theater: connecting satellites and sequencing to shinrin-yoku. Journal of Physiological Anthropology, 35 (1).

Dean, J.H., Shanahan, D.F., Bush, R., Gaston, K.J., Lin, B.B., Barber, E., Franco, L., \& Fuller, R.A. (2018). Is Nature Relatedness Associated with Better Mental and Physical Health? International Journal of Environmental Research and Public Health, 15 (7), 1371. Retrieved from https://doi.org/10.3390/ijerph15071371.

Dunlap, R.E. (2008). The New environmental paradigm scale: From marginality to worldwide use. The Journal of Environmental Education, 40 (1), 3-18.

Dunlap, R.E., \& Van Liere, K.D. (1978). The new environmental paradigm: A proposed measuring instrument and preliminary results. The Journal of Environmental Education, 9 (4), 10-19.

Franěk, M. (2012). Nature Relatedness Scale. Envigogika, 7 (1), 1-10. Retrieved from http:// dx.doi.org/10.14712/18023061.69.

Hines, J.M., Hungerford, H.R., \& Tomera, A.N. (1987). Analysis and synthesis of research and responsible environmental behavior: A meta-analysis. Journal of Environmental Education, 18 (2), 1-8.

Hollweg, K.S. Taylor, J.R., Bybee, R.W., Marcinkowski, T.J., McBeth, W.C., \& Zoido, P. (2011). Developing a framework for assessing environmental literacy. Washington, DC: North American Association for Environmental Education.

Hungerford, H.R., Volk, T., Wilke, R., Champeau, R., Marcikowski, T., May, T., Bluhm, W., \& McKeown-Ice, R. (1994). Environmental Literacy Framework. Environmental Education Literacy Consorcium. Cardonbale, Illinois:, University of South Illinois.

Janovec, J., Kroufek, R., Chytrý, V., \& Dolejšová, J. (2016). Qualitative view on environmental and technological literacy of pre-service primary teachers. INTED 2016 proceedings. Valencia: IATED.

Kellert, S., \& Wilson, E.O. (eds.). (1993). The Biophilia Hypothesis. Washington: Shearwater Books, 484 p.

Kroufek, R., \& Chytrý, V. (2015). The nature relatedness of the undergraduate students in the Czech Republic. ICERI 2015 proceedings. Seville: IATED.

Liefländer, A.K., Fröhlich, G., Bogner, F.X., \& Schultz, P.W. (2013) Promoting connected- 
ness with nature through environmental education. Environmental Education Research, 19 (3), 370-384.

Mayer, F.S., \& Frantz, C.M. (2004). The connectedness to nature scale: A measure of individuals' feeling in community with nature. Journal of Environmental Psychology, 24 (4), 503-515.

Morse, D.T. (1999). Minsize2: A computer program for determining effect size and minimum sample for statistical significance for univariate, multivariate, and nonparametric tests. Educational and Psychological Measurement, 59 (3), 518-531.

Nisbet. E.K. (2011). A Nature Relatedness Intervention to Promote Happiness and Environmental Concern. Ottawa, Ontario: Carleton University.

Nisbet, E.K., Zelenski, J.M., \& Murphy, S.A. (2009). The Nature relatedness scale. Linking individuals' connection with nature to environmental concern and behavior. Environment and Behavior, 41 (5), 715-740.

Nisbet, E.K., Zelenski, J.M., \& Murphy, S.A. (2011). Happiness is in our Nature: Exploring Nature Relatedness as a Contributor to Subjective Well-Being. Journal of Happiness Studies, 12 (2), 303-322.

Nisbet, E.K., \& Zelenski, J.M. (2011). Underestimating nearby nature: Affective forecasting errors obscure the happy path to sustainability. Psychological Science, 22 (9), 1101-1106.

Nisbet, E.K., \& Zelenski, J.M. (2013). The NR-6: a new brief measure of nature relatedness. Frontiers in Psychology, 4, 1-11. Retrieved from https://doi.org/10.3389/ fpsyg.2013.00813.

Nisbet, E.K., Zelenski, J.M., \& Murphy, S.A. (2011). Happiness Is in Our Nature: Exploring Nature Relatedness as a Contributor to Subjective Well-Being. Journal of Happiness Studies, 12 (2), 303-322.

Perkins, H.E. (2010). Measuring love and care for nature. Journal of Environmental Psychology, 30 (4), 455-463.

Peyton, R., \& Miller, B. (1980). Developing an internal locus of control as a prerequisite to environmental action taking. In Sacks, A. et al. (Eds.) Current issues VI: The yearbook of environmental education and environmental studies. Columbus: ERIC, 173-192.

Restall, B., \& Condrad, E. (2015). A literature review of connectedness to nature and its potential for environmental management. Journal of Environmental Management, 159, 264-278.

Robinson, D., H., \& Levin, J.R. (1997). Reflections on statistical and substantive significance with a slice of replication. Educational Researcher, 26 (5), 21-27.

Robottom, I., Malone, K., \& Walker, R. (2000). Case studies in environmental education: Policy and practice. Geelong Vic Australia: Deakin University Press.

Rosenthal, R., Rosnow, R.L., \& Rubin, D.B. (2000). Contrasts and effect sizes in behavioral research: A correlational approach. Cambridge: Cambridge university press.

Roth, C.E. (1992). Environmental literacy: Its Roots, Evolution and Directions in the 1990s. Columbus, Ohio: ERIC Clearinghouse for Science, Mathematics and Environmental Education.

Říčan, J. (2016). Metakognice a metakognitivní strategie jako teoretické a výzkumné kon- 
strukty a jejich uplatnění v moderní pedagogické praxi (Metacognition and metacognitive strategies as theoretical and research constructs and their application in modern pedagogical practice). Most: Hněvín.

Schultz, P.W. (2002). Inclusion with nature: The psychology of human-nature relations. In Schmuck, P., \& Schultz, W.P. (Eds.). Psychology of sustainable development. Norwell: Kluwer Academic, 62-78.

Sheskin, D.J. (2007). Handbook of parametric and nonparametric statistical procedures. $\left(4^{\text {th }}\right.$ ed.). Boca Raton, FL: Chapman \& Hall/CRC.

Siegel, S., \& Castellan, N.J. (1988). Nonparametric statistics for the behavioral sciences. (2nd ed.) New York: McGraw-Hill.

Statsoft (2015). Statistica 12. Retrieved from http://www.statsoft.cz/.

Thomas, J.R., \& Nelson, J.K. (2001). Research methods in physical activity. (4 ${ }^{\text {th }}$ ed.). Champaign, IL: Human Kinetics.

Wilson, E.O. (1984). Biophilia: The human bond with other species. Cambridge: Harvard University Press, 157 p.

Windhorst, E., \& Williams, A. (2015). Growing Up, Naturally: The Mental Health Legacy of Early Nature Affiliation. Ecopsychology, 7 (3), 115-125.

Zelenski, J.M., Dopko, R.L., \& Capaldi, C.A. (2015). Cooperation is in our nature: Nature exposure may promote cooperative and environmentally sustainable behavior. Journal of Environmental Psychology, 42, 24-31.

Zelnski, J.M. \& Nisbet, E.K. (2014). Happiness and Feeling Connected: The Distinct Role of Nature Relatedness. Environment and Behavior, 46 (1), 3-23. 